\title{
Simulated nitrate leaching in annually cover cropped and perennial living mulch corn production systems
}

\author{
J.S. Andrews, Z.P. Sanders, M.L. Cabrera, N.S. Hill, and D.E. Radcliffe
}

\begin{abstract}
Corn (Zea mays) grown in the southern Piedmont requires 200 to $280 \mathrm{~kg}$ nitrogen (N) ha ${ }^{-1}$ annually and requires up to $0.87 \mathrm{~cm}$ of water per day, making groundwater systems susceptible to nitrate $\left(\mathrm{NO}_{3}^{-}\right)$leaching. A perennial white clover (Trifolium repens L.) living mulch (LM) system may reduce $\mathrm{NO}_{3}-\mathrm{N}$ leaching by using legume $\mathrm{N}$ to replace mineral $\mathrm{N}$, though little information is available on such a system in the southern Piedmont. Therefore, a HYDRUS-1D model was used to simulate water and $\mathrm{NO}_{3}-\mathrm{N}$ flux in three cover crop systems. Cereal rye (Secale cereal L.) (CR), crimson clover (Trifolium incarnatum L.) (CC), and a white clover LM were fertilized with 280,168 , and $56 \mathrm{~kg} \mathrm{~N} \mathrm{ha}^{-1}$. The HYDRUS-1D model was calibrated and validated with observed water contents and $\mathrm{NO}_{3}-\mathrm{N}$ data that were collected over two years. Water and $\mathrm{NO}_{3}-\mathrm{N}$ flux models were created for each treatment and evaluated using coefficient of determination, percentage bias, and index of agreement, and showed good agreement to observed data. Nitrate leaching below $1 \mathrm{~m}$ in 2015/2016 was $23.5,12.7$, and $21.4 \mathrm{~kg} \mathrm{ha}^{-1}$ for the CC, LM, and CR treatments, respectively, but was less than $1 \mathrm{~kg} \mathrm{ha}^{-1}$ for all treatments in 2016/2017 due to prolonged drought. Differences in leached $\mathrm{NO}_{3}-\mathrm{N}$ among treatments were attributed to variation in mineral $\mathrm{N}$ application rate and $\mathrm{NO}_{3}-\mathrm{N}$ uptake by cover crops. Overall, results suggest that the use of a perennial LM system may reduce $\mathrm{NO}_{3}-\mathrm{N}$ leaching when compared to annual $\mathrm{CC}$ and $\mathrm{CR}$ cover crop systems.
\end{abstract}

Key words: corn—cover crop—HYDRUS-1D—living mulch—nitrate leaching-Piedmont

\begin{abstract}
Intense rainfall events and significant erosion from agricultural practices make soils in the southern Piedmont region of the United States unproductive without careful management of irrigation and supplemental fertilizer (Adams et al. 1970; Endale et al. 2008; Thomas et al. 1989). Water and nitrogen $(N)$ are therefore important inputs for crop production, with higher yielding varieties of crops demanding greater quantities of water and nutrients during the growing season. In this region, 200 to $280 \mathrm{~kg} \mathrm{~N} \mathrm{ha}^{-1}$ is required for corn (Zea mays) growth annually, applied mainly as mineral N (Lee et al. 2015; Raun et al. 1999). Cecil soils, which comprise roughly two-thirds of the land area of the southern Piedmont (Endale et al. 2008; Hendrickson et al. 1963; Radcliffe and West 2000), are well-drained due to their sandy upper horizons and lower clay horizons with large aggregates and strong structure (Bruce et al.
\end{abstract}

et al. 2011; McCracken et al. 1994). Annual legumes such as vetch are not as efficient in preventing $\mathrm{NO}_{3}-\mathrm{N}$ leaching as cereal rye because of the added $\mathrm{N}$ to the system from $\mathrm{N}$ fixation (McCracken et al. 1994; Campiglia et al. 2011). Even cereal rye has its limitations to immobilizing excess $\mathrm{N}$, and leaching can be significant when grown in a corn system receiving high rates of mineral $N$ (Rasse et al. 2000). A key to minimizing $\mathrm{NO}_{3}-\mathrm{N}$ leaching is quick establishment of the cover crop following row crop harvest (Hashemi et al. 2013; Staver and Brinsfield 1998). Some producers have utilized aerial seeding to establish the cover crop prior to corn harvest in the northern regions of US corn production (Singer 2008).

A problem with utilizing cover crops in corn production systems in the southeastern United States is the delay in late summer harvest and the time when environmental conditions are optimum for cover crop establishment-usually in mid-October. Therefore, other cover crop strategies may be more appropriate than traditional annual cover crops. Living mulches (LM) are perennial cohort crops that provide ground cover throughout the growing season (Hartwig and Ammon 2002). They decrease soil erosion (Siller et al. 2016; Wall et al. 1991), suppress weeds (Enache and Ilnicki 1990; Hiltbrunner et al. 2007), and reduce insect pests (Frank and Liburd 2005; Litsinger and Moody 1976). Similar to annual cover cropping systems, perennial LM systems are capable of reducing $\mathrm{NO}_{3}-\mathrm{N}$ leaching through uptake of excess soil N (Liedgens et al. 2004; Ochsner et al. 2010). A perennial white clover (Trifolium repens L.) LM system in the southern Piedmont region of the United States has been shown to consistently provide over 100 $\mathrm{kg} \mathrm{N} \mathrm{ha}{ }^{-1}$ to corn and re-establish quickly after harvest (Sanders et al. 2017; Andrews et al. 2018). The perennial nature of LM cover crops eliminates the need for cover crop establishment (Sanders et al. 2017) and, thus,

Hahne et al. 1977). Conservation practices such as the use of cover crops, no-till planting, and fertilizer management are capable of reducing $\mathrm{NO}_{3}-\mathrm{N}$ leaching when properly managed (Angle et al. 1989; Arora and Juo 1982; Kanwar et al. 1988; Kladivko et al 2014; Yadav 1997). Cereal rye (Secale cereal L.) and hairy vetch (Vicia villosa Roth) cover crops reduce $\mathrm{NO}_{3}-\mathrm{N}$ leaching by utilizing and immobilizing excess soil $\mathrm{NO}_{3}-\mathrm{N}$ during winter fallow periods (Brandi-Dohrn et al. 1997; Ketterings et al. 2015; Krueger
Joshua S. Andrews (corresponding author) is a nutrient management agrologist at British Columbia Ministry of Agriculture, Abbotsford, British Columbia, Canada. Zachary P. Sanders is a research technologist at Penn State University, State College, Pennsylvania, United States. Miguel L. Cabrera, Nicholas S. Hill, and David E. Radcliffe are professors at the University of Georgia, Department of Crop and Soil Science, Athens, Georgia, United States. 
may provide additional utilization of excess nutrients following crop harvest. However, N supply from leguminous LM cover crops to corn make such systems potential contributors to $\mathrm{N}$ leaching. Additionally, the effect of the white clover LM corn production system on $\mathrm{NO}_{3}-\mathrm{N}$ leaching is currently unknown.

Hydrologic and water quality models are increasingly being using to determine the impacts of land use, $\mathrm{N}$ fertilization, and other conservation practices on nutrient fate within agroecosystems and are considered appropriate and valuable tools to assess the impact of management practices on $\mathrm{N}$ leaching (Berntsen et al. 2005; Moriasi et al. 2015; Tafteh and Sepaskhah 2012; Wang et al. 2014). Model use is particularly valuable when economic or technical conditions make long-term field experiments difficult ( $\mathrm{Li}$ and Liu 2011), though agreement between observed and predicted data is necessary to reduce the uncertainty of model predictions (Moriasi et al. 2015). Previous research efforts have included modeling of $\mathrm{NO}_{3}-\mathrm{N}$ leaching in systems that include white clover as a $\mathrm{N}$ source (Berntsen et al. 2005; Wu and McGechan 1999) while other models have focused mainly on corn and mineral fertilizer (Tafteh and Sepaskhah 2012; Wang et al. 2014). Although these studies do not focus on the living mulch corn system, they do show that modeling these crops can be successful when determining $\mathrm{NO}_{3}-\mathrm{N}$ fate. HYDRUS-1D was chosen for this experiment as it has been used to simulate $\mathrm{NO}_{3}-\mathrm{N}$ leaching in similar studies, provides relative ease of use, and allows models to be quickly evaluated through statistical and graphical performance measures (Moriasi et al. 2015; Tafteh and Sepaskhah 2012; Wang et al. 2014). Therefore, the objectives of this study were to (1) use observed data to calibrate and validate a HYDRUS-1D model to simulate water and $\mathrm{NO}_{3}-\mathrm{N}$ transport in three different cover crop corn production systems and (2) use the model to compare water and $\mathrm{NO}_{3}-\mathrm{N}$ transport in the three systems.

\section{Materials and Methods}

Site Description. The study was performed from October of 2014 through February of 2017 at the J. Phil Campbell Research and Education Center in Watkinsville, Georgia (3352'09.5" N 8326'59.8" W). The soil is classified as a Cecil sandy loam (fine, kaolinitic, thermic typic Kanhapludults), which was confirmed by pedological analysis of a soil profile adjacent to the research plots. A soil moisture release curve based on the van Genuchten (1980) equation was created using the evaporation method (Arya 2002) with a Decagon HYPROP device (Decagon Devices, Pullman, Washington) from several soil cores collected from the plot area. The soil moisture release curve indicated that field capacity $(-0.03 \mathrm{MPa})$ was $0.24 \mathrm{~cm}^{3}$ water $\mathrm{cm}^{-3}$ soil and wilting point $(-1.5 \mathrm{MPa})$ was $0.11 \mathrm{~cm}^{3}$ water $\mathrm{cm}^{-3}$ soil. Weather data were collected by The Georgia Environmental Monitoring Network station adjacent to the plot area (http://weather.uga.edu/).

Experimental Design. The cereal rye (CR), crimson clover (CC), and LM treatments were assigned to a randomized complete block design with six replications. Soils in the experimental area were sampled and $\mathrm{pH}$ and mineral deficiencies amended according to soil test. The CR treatment received a total of $280 \mathrm{~kg} \mathrm{~N} \mathrm{ha}{ }^{-1}$ supplemental fertilization that was split into two applications based on a recommendation from Lee et al. (2015). The CC and LM received lower supplemental $\mathrm{N}$ rates based upon $\mathrm{N}$ credits from the cover crops established in a previous study to provide a similar amount of available $\mathrm{N}$ as the CR treatment (Andrews et al. 2018; Sanders et al. 2017). CR plots were fertilized with $56 \mathrm{~kg} \mathrm{~N} \mathrm{ha}^{-1}$ at planting using granular urea. At the V6 stage of corn development, the CR, CC, and LM treatments received 224,168 , and $56 \mathrm{~kg} \mathrm{~N} \mathrm{ha}^{-1}$, respectively, also as granular urea.

Agronomic Management. Prior to cover crop planting, soils were tested for $\mathrm{pH}$ and extractable phosphorus (P) and potassium $(\mathrm{K})$ by the University of Georgia Soil Testing Laboratory using the Mehlich 1 method (Beck et al. 2004). Soils were limed and fertilized so that $\mathrm{pH}$ was above 6.2 and extractable $\mathrm{P}$ and $\mathrm{K}$ were above 45 and 140 ppm, respectively. On October 17, 2014, land was disked and firmed with a cultipacker before CR, CC, and LM cover crop plots were seeded by hand at rates of 100, 28, and $13 \mathrm{~kg} \mathrm{ha}^{-1}$, respectively. The CC and CR plots were killed with a broadcast application of dicamba (3,6-Dichloro-2-methoxybenzoic acid) and glyphosate (N-(phosphonomethyl) glycine) at respective rates of 1.20 and 1.12 $\mathrm{kg}$ a.i. ha $\mathrm{ha}^{-1}$ on March 16 and April 8, 2015. All herbicides were applied by a state licensed pesticide applicator, and all applications were made during environmental conditions when risk for off-target movement of pesticides was low. Additionally, the pesticide formulations, application equipment, and application methods that were used ensured that the risk of off-target movement of pesticides was further reduced (Carlsen et al. 2006). A 20 $\mathrm{cm}$ banded application of the herbicides at the same rates was applied to the LM plots on April 8, 2015, using a hooded sprayer. The banded application was centered on 90 $\mathrm{cm}$ rows. A John Deere 7300 MaxEmerge no-till planter (John Deere, Moline, Illinois) was used to plant corn (DeKalb DKC6469, GENVT3P) at a population density of 90,000 plants ha ${ }^{-1}$ on April 21, 2015. Plot size allowed for eight rows of corn per plot. Corn was harvested on August 16, 2015.

Annual cover crops were reestablished in the same plot areas in October of 2015 using the same seeding rates as 2014. On March 23 and April 4, 2016, herbicide applications were made to the CR and CC plots, while herbicide applications were made to the LM plots on April 14. All herbicides were applied as previously described. Corn was planted at the same seeding rate and methods as the previous year on April 28, 2016. Nitrogen fertilization also occurred in the same rate and method as 2015. Corn from all plots was harvested on August 8, 2016, and cover crops were reseeded on the same plots in November of 2016.

Field Instrumentation, Irrigation Scheduling, and Soil Sampling. Campbell Scientific Model CS625 reflectometers (Logan, Utah) were installed under the corn row to monitor soil water content in the center of each plot. The rods were $30 \mathrm{~cm}$ in length and installed at 30 degree angles to measure water content at the 0 to 15 and 15 to $30 \mathrm{~cm}$ depths. Water content data were measured and recorded on 10 minute intervals and stored on data loggers within three replications of the experiment. Irrigation was provided on an as-needed basis during the cropping season, which was determined by the soil moisture sensors. Overhead irrigation was used to maintain the water content of the surface 0 to $15 \mathrm{~cm}$ between $40 \%$ to $90 \%$ available water content in 2015, but demand for water from other researchers exceeded the ability of the water resources during 2016, a drought year. Thus, there were occasions when the soil moisture content fell below the desired range.

Two porous cup suction samplers (lysimeters) were placed $1 \mathrm{~m}$ apart in the center of each plot alongside the corn row in the 
other three replications. A Giddings soil core sampler was used to remove soil to a restrictive Bt2 layer, approximately $75 \mathrm{~cm}$ deep. A $1 \mathrm{~m}$ long lysimeter was installed with a slurry of Bt horizon soil to cover the sampler's ceramic cup, and a slurry of A horizon soil and kaolinite filled the remainder of the augered hole to prevent preferential flow down the side of the lysimeters. Polyvinyl chloride (PVC) pipes with caps were placed over the tops of the lysimeters to prevent damage to the lysimeters and minimize the opportunity for preferential flow.

Lysimeters were purged weekly and a 7 $\mathrm{kPa}$ vacuum was applied using a handheld vacuum pump and kept under vacuum for 18 to 36 hours. Water was aspirated from the lysimeters using a handheld vacuum pump, and a $25 \mathrm{~mL}$ aliquot of water from each lysimeter was combined for $\mathrm{NO}_{3}-\mathrm{N}$ analysis. Occasionally only one lysimeter per plot contained water from which a $50 \mathrm{~mL}$ aliquot was sampled for analysis. Eight soil cores were randomly sampled to a depth of $15 \mathrm{~cm}$ weekly from each plot using a $1.5 \mathrm{~cm}$ diameter handheld soil probe. Soil cores were taken from the center two rows of the plot, combined, air dried, and stored at $4{ }^{\circ} \mathrm{C}$.

Laboratory Analysis. Five grams of soil were extracted with $40 \mathrm{~mL}$ of $1 \mathrm{M}$ potassium chloride $(\mathrm{KCl})$ for $\mathrm{NO}_{3}-\mathrm{N}$ concentration. Water samples and soil extracts were analyzed for $\mathrm{NO}_{3}-\mathrm{N}$ concentration using a Timberline TL-2800 Ammonia Analyzer (Boulder, Colorado).

Weekly changes in clover mass in the LM plots were determined using a rising plate meter (RPM) as described by Sanders et al. (2017). Ten to twelve RPM height measurements were made within the center two rows in each LM plot weekly to determine clover mass. Hand harvested clover samples were subjected to Kjeldahl digestion and $\mathrm{N}$ content determined using a Timberline TL-2800 Ammonia Analyzer. Total $\mathrm{N}$ in the white clover was calculated weekly as the product of white clover mass and the total $\mathrm{N}$ content of the clover. Decline in clover mass from one week to the next was used to estimate $\mathrm{N}$ release from the clover.

Model Selection and Description. Porouscup suction lysimeters are a cost-efficient means of obtaining leachate from a large number of treatments (Andraski et al. 2000). However, they are not capable of quantifying water drainage. Therefore, a modeling approach was used with solute concentra- tion data to evaluate $\mathrm{NO}_{3}-\mathrm{N}$ movement HYDRUS-1D was selected for simulating water and $\mathrm{NO}_{3}-\mathrm{N}$ loss in the different cover crop corn production systems in our study due to the relative ease of use and use in similar research (Tafteh and Sepaskhah 2012; Wang et al. 2010). The model was used to simulate water and $\mathrm{NO}_{3}-\mathrm{N}$ movement from planting in April of 2015 and 2016 through February of the following year based on mean data from each treatment. One model was used to simulate each corn-cover crop system per period. The one-dimensional model was developed to simulate the vertical movement of soil water, heat, and solutes in variably saturated-unsaturated media (Šimůnek et al. 2016) using a numerical solution to the Richards (1931) equation 1:

$\frac{\partial \theta}{\partial t}=\frac{\partial}{\partial z}\left[K(h) \times\left(\frac{\partial h}{\partial z}+1\right)\right]-S$,

where $h(\mathrm{~cm})$ is the pressure head, $z(\mathrm{~cm})$ is the gravitational potential head, $t$ (d) is time, and $S\left(\mathrm{~cm} \mathrm{~d}^{-1}\right)$ is root water uptake rate.

The van Genuchten (1980) soil water retention equation 2 was used to describe water retention in the experimental soil:

$\theta(h)=\frac{\theta_{s}-\theta_{r}}{\left[1+(-\alpha h)^{n}\right]^{m}}+\theta_{r}$,

where $\alpha\left(\mathrm{cm}^{-1}\right), m$ (dimensionless), and $n$ (dimensionless) are fitted parameters of the van Genuchten equation; $\theta(h)$ is the volumetric water content $\left(\mathrm{cm}^{3} \mathrm{~cm}^{-3}\right)$; $\theta_{s}$ is the saturated volumetric water content $\left(\mathrm{cm}^{3}\right.$ $\mathrm{cm}^{-3}$ ); and $\theta$ is the residual volumetric water content $\left(\mathrm{cm}^{3} \mathrm{~cm}^{-3}\right)$. The van Genuchten (1980) unsaturated hydraulic conductivity equation 3 was used to describe unsaturated flow in the experimental soil:

$$
K(h)=K_{s}\left|\frac{\theta(h)-\theta_{r}}{\theta_{s}-\theta_{r}}\right|^{0.5}\left(1-\left\{1-\left|\frac{\theta(h)-\theta_{r}}{\theta_{s}-\theta_{r}}\right|^{1 / m}\right\}\right),
$$

where $K$ is the saturated hydraulic conductivity $\left(\mathrm{cm} \mathrm{d}^{-1}\right), m$ is the fitted parameter from equation 2 , and it is assumed that $m=$ $1-1 / n$.

Initial estimates of the water retention parameters for equations 2 and 3 were determined by the evaporation method (Arya 2002) using a Decagon HYPROP device (Pullman, Washington) from soil samples taken from each soil layer in a pit adjacent to the experiment. Soil water retention parameters were optimized through auto-calibration in the top two soil horizons across all models using collected soil moisture data and the inverse solution function in HYDRUS-1D. Since there were no soil moisture data for the lower two soil layers and the inverse solution function in HYDRUS-1D required data from those depths, the soil water retention parameters in the two remaining soil horizons were not changed from the initial parameters. Soil physical properties and final soil water retention parameters are in table 1. Soil samples for bulk density $\left(\rho_{b}\right)\left(\mathrm{g} \mathrm{cm}^{-3}\right)$ were also collected and measured following standard procedures (USDA 1996).

Model Domain and Boundary Conditions. The HYDRUS-1D model used a $100 \mathrm{~cm}$ profile with four materials to simulate four soil horizons and their water retention parameters (table 1). A total of 101 nodes were used in the model space with an equal density of one node per centimeter of model space. The upper boundary condition was an atmospheric boundary with surface runoff and the lower boundary condition was free drainage. Observation nodes were placed at 8 and $23 \mathrm{~cm}$ below the soil surface to represent the center of time domain reflectometers installed within the corn rows. Observed data were input at each observation node as the average daily volumetric water content $\left(\mathrm{cm}^{3} \mathrm{~cm}^{-3}\right)$ of the three replications.

Solute transport had a concentration flux boundary condition at the top of the model space with no concentration gradient as the lower boundary condition. Observation nodes were placed at 8 and $75 \mathrm{~cm}$ below the soil surface to represent points where soil water $\mathrm{NO}_{3}-\mathrm{N}$ concentration was sampled either by soil sampling or suction samplers. Observed data were input in each observation node as the daily average $\mathrm{NO}_{3}-\mathrm{N}$ concentration of the three replications. Granular urea fertilizer $\mathrm{N}$ was used as an input time variable for the upper boundary condition and the soil water concentration calculated based upon the amount of irrigation water applied. Nitrogen release from the clover in LM plots was added when clover mass declined from one week to the next.

Water Uptake and Evapotranspiration. The Feddes et al. (1978) model (equation 4) was used to describe root water uptake in HYDRUS-1D:

$S(h)=\alpha(h) S_{\max }$, 
Table 1

Soil properties and hydraulic parameters based on the van Genuchten equation for water retention used in the HYDRUS-1D model for the Watkinsville, Georgia, experimental site. Initial uncalibrated parameters as measured by the evaporation method for the top two soil layers are provided in the last two rows.

\begin{tabular}{|c|c|c|c|c|c|c|c|c|c|c|c|}
\hline \multirow{2}{*}{$\begin{array}{l}\text { Soil layer } \\
\text { (cm) }\end{array}$} & \multirow[b]{2}{*}{ Texture } & \multicolumn{3}{|c|}{ Particle fraction (\%) } & \multirow[b]{2}{*}{$\rho_{b}\left(\mathbf{g ~ c m}^{-3}\right)$} & \multirow[b]{2}{*}{$\theta_{r}\left(\mathbf{c m}^{3} \mathbf{c m}^{-3}\right)$} & \multirow[b]{2}{*}{$\theta_{s}\left(\mathbf{c m}^{3} \mathbf{c m}^{-3}\right)$} & \multirow[b]{2}{*}{$\alpha\left(\mathbf{c m}^{-1}\right)$} & \multirow[b]{2}{*}{$n$} & \multirow[b]{2}{*}{$I$} & \multirow[b]{2}{*}{$K_{s}\left(\mathrm{~cm} \mathrm{~d}^{-1}\right)$} \\
\hline & & Sand & Silt & Clay & & & & & & & \\
\hline 0 to 18 & Sandy loam & 55 & 29 & 16 & 1.38 & 0.04 & 0.30 & 0.0062 & 1.28 & 0.5 & 61.1 \\
\hline 18 to 38 & Clay loam & 40 & 30 & 30 & 1.52 & 0.03 & 0.27 & 0.0005 & 1.33 & 0.5 & 66.4 \\
\hline 38 to 72 & Clay & 36 & 22 & 42 & 1.42 & 0.33 & 0.54 & 0.0535 & 1.40 & 0.5 & 89.5 \\
\hline 72 to 100 & Clay & 34 & 12 & 54 & 1.46 & 0.11 & 0.46 & 0.0051 & 1.42 & 0.5 & 10.1 \\
\hline 0 to 18 & - & - & - & - & - & 0.28 & 0.38 & 0.0257 & 3.53 & 0.5 & 58.2 \\
\hline 18 to 38 & - & - & - & - & - & 0.21 & 0.38 & 0.0036 & 1.14 & 0.5 & NA \\
\hline
\end{tabular}

Notes: $\rho_{b}=$ bulk density. $\theta_{r}=$ residual volumetric water content. $\theta_{s}=$ saturated volumetric water content. $K_{s}=$ saturated hydraulic conductivity.

where $\alpha(h)$ is the coefficient of root water uptake and $S_{\max }$ is the potential water uptake $\left(\mathrm{d}^{-1}\right)$. Root water uptake is zero at saturation $\left(h_{0}\right)$ due to lack of oxygen $(\mathrm{O})$ and increases linearly as pressure heads decrease to $h_{1}$. Root uptake was optimum (no water stress) for pressure heads within the range of $h_{1}$ to $h_{2}$. From $h_{2}$ to $h_{3}$, root uptake decreased linearly and stopped at pressure heads below $h_{3}$ due to insufficient soil water. Based on $R^{2}$ provided in model output, the root water uptake parameters that provided the best fit to observed data and subsequently used in this model for all crops were $h_{0}=-15 \mathrm{~cm}$, $h_{1}=-30 \mathrm{~cm}, h_{2}=-400 \mathrm{~cm}, h_{3}=-15,330$ $\mathrm{cm}$, and $S_{\max }=0.5 \mathrm{~cm} \mathrm{~d}^{-1}$. For reference, the parameters used for corn in Wesseling et al. (1991) are $h_{0}=-15 \mathrm{~cm}, h_{1}=-30 \mathrm{~cm}$, $h_{2}=-600 \mathrm{~cm}, h_{3}=-8,000 \mathrm{~cm}$, and $S_{\max }=$ $0.5 \mathrm{~cm} \mathrm{~d}^{-1}$.

Input rooting depth for corn increased linearly from $0 \mathrm{~cm}$ at planting to a final depth of $72 \mathrm{~cm}$ after 82 days of growth and remained at that depth until harvest (Mengel and Barber 1974). An additional $10 \mathrm{~cm}$ of rooting depth was added to the corn in the LM treatment to simulate competitive water uptake by the intercropped clover (Kurtz et al. 1952). Rooting depth increased linearly from 0 to $50 \mathrm{~cm}$ for the $\mathrm{CC}$ and $\mathrm{CR}$ cover crops during both model periods, and from 0 to $40 \mathrm{~cm}$ in the LM cover crop during the 2015/2016 model period (Caradus 1990; Sainju et al. 1998). Initial to final rooting depth for all cover crops occurred from planting to 60 days after planting (DAP). In the 2016/2017 model period, rooting depth of the LM cover crop was input as 10 $\mathrm{cm}$ at corn harvest and then increased linearly to $40 \mathrm{~cm}$ after 45 days of growth. As HYDRUS-1D only allows for one root distribution and two crops are simulated in each model, a root distribution to represent corn and all three cover crops was used. Seventy percent of roots were placed in the top 20 $\mathrm{cm}$ of soil, which generally occurs in all four crops (Caradus 1990; Mengel and Barber 1974; Sainju et al. 1998). Rooting distribution decreased linearly from 20 to $72 \mathrm{~cm}$ (the top of a restrictive clay layer) for the remaining $30 \%$ of roots. While the same rooting distribution was used for multiple cover crop systems, it should be noted that each of the three corn-cover crop simulations was performed independently and not incorporated into one model.

Potential evapotranspiration (PET) was separated into evaporation and transpiration in the HYDRUS-1D model by the input of leaf area index (LAI). In the CC and CR models, LAI of corn increased linearly from 0 to 3.0 from $7 \mathrm{DAP}$ to $67 \mathrm{DAP}$, and then from 3.0 to 3.5 linearly over the next 30 days and remained until harvest (Timlin et al. 2014). For the LM models, an additional LAI of 1.5 was added to account for competitive water uptake by the white clover (Kurtz et al. 1952). Leaf area index of the CC, $\mathrm{CR}$, and LM plots increased linearly from 0 to 3.0 from 7 days after cover crop seeding (DAS) to 69,37 , and 80 DAS, respectively. Leaf area index increased linearly from 3.0 to 5.1 and 3.0 to 4.6 until 82 and 89 DAS for the CC and LM treatments, respectively (den Hollander et al. 2007; Ellen 1993). The LAI remained constant thereafter until the end of February in the following year (den Hollander et al. 2007). In the next model period, white clover in the LM treatment was not reseeded, so LAI followed the same development as the previous LM model, but began with an LAI of 1.0. Therefore, LAI of the white clover increased linearly from 1.0 to 3.0 after 52 DAS (though no white clover was planted), and then from 3.0 to 4.6 during the 56 to 65 DAS time period.

Soil Nitrogen Transport and Transformation. Linear adsorption and chemical equilibrium in the advectiondispersion equation (ADE) was used to estimate solute transport in HYDRUS (5):

$$
\begin{aligned}
& \frac{\partial\left(\theta c+\rho_{b} K_{d} c\right)}{\partial t}=-\frac{\partial}{\partial t}\left(J_{w} c-\theta D_{e} \frac{\partial c}{\partial z}\right) \\
& -\theta \mu c-S c,
\end{aligned}
$$

where $c$ is the dissolved concentration of the solute $\left(\mathrm{g} \mathrm{cm}^{-3}\right), t$ is time $(\mathrm{d}), K_{d}$ is an adsorption coefficient $\left(\mathrm{cm}^{3} \mathrm{mg}^{-1}\right), D$ is the effective dispersion coefficient $\left(\mathrm{cm}^{2} \mathrm{~d}^{-1}\right), z$ is the vertical dimension $(\mathrm{cm}), J_{w}$ is the vertical Darcy water flux $\left(\mathrm{cm} \mathrm{d}^{-1}\right)$, and $\mu$ is the first-order rate constant for solute transformation processes $\left(\mathrm{d}^{-1}\right)$.

Mineralization and nitrification can occur rapidly, and concentrations of potentially mineralizable $\mathrm{N}$ (PMN) and ammonium $\left(\mathrm{NH}_{4}\right)$ are low in Cecil soils (Dubey 1968; Anderson 1960; Cabrera 1993). Therefore, $\mathrm{PMN}$ and $\mathrm{NH}_{4}-\mathrm{N}$ in the soil profile were considered together as a bulk solute. Other relevant HYDRUS-1D $\mathrm{NO}_{3}-\mathrm{N}$ leaching research used a similar strategy involving transformations of $\mathrm{PMN}$ and $\mathrm{NH}_{4}-\mathrm{N}$ into $\mathrm{NO}_{3}-\mathrm{N}$ (Tafteh and Sepaskhah 2012; Wang et al. 2010).

An $\mathrm{N}$ chain model was used to simulate $\mathrm{N}$ transformations in the CC, LM, and CR models. The model included the nitrification of $\mathrm{NH}_{4}-\mathrm{N}$ and PMN to $\mathrm{NO}_{3}-\mathrm{N}$ as well as denitrification from $\mathrm{NO}_{3}-\mathrm{N}$ to dinitrogen/ nitrous oxide $\left(\mathrm{N}_{2} / \mathrm{N}_{2} \mathrm{O}\right)$. The intermediate product of nitrification, $\mathrm{NO}_{2}-\mathrm{N}$, was ignored to simplify the chain model (Bradshaw et al. 2013). The first-order reaction rates for the change in $\mathrm{NH}_{4}-\mathrm{N}+\mathrm{PMN}$ (equation 6) and $\mathrm{NO}_{3}-\mathrm{N}$ (equation 7) concentrations that result from the $\mathrm{N}$ chain models were

$\frac{\partial\left[\mathrm{NH}_{4}-\mathrm{N}+\mathrm{PMN}\right]}{\partial t}=-k\left[\mathrm{NH}_{4} \mathrm{~N}+\mathrm{PMN}\right](6)$

and 


$$
\frac{\partial\left[\mathrm{NO}_{3}-\mathrm{N}\right]}{\partial t}=-k\left[\mathrm{NH}_{4} \mathrm{~N}+\mathrm{PMN}\right]-\mu\left[\mathrm{NO}_{3} \mathrm{~N}\right]
$$

where $k$ and $\mu$ are the nitrification and denitrification rate coefficients $\left(\mathrm{d}^{-1}\right)$, respectively, and $t$ is time (d). It was assumed that these coefficients only applied to $\mathrm{N}$ in solution. Based on percentage bias (PBIAS), $R^{2}$, and $d$, the nitrification rate constant of $0.2 \mathrm{~d}^{-1}$ was found to provide an acceptable fit to observed data and was within ranges reported in the literature (table 2) (Hanson et al. 2006; Iskandar and Selim 1981; Ling and El-Kadi 1998; Lotse et al. 1992). Complete denitrification of $\mathrm{NO}_{3}-\mathrm{N}$ was assumed to occur under saturated conditions, and rate constants were set the same as for nitrification (table 2). Adsorption coefficients for $\mathrm{NH}_{4}-\mathrm{N} / \mathrm{PMN}$ and $\mathrm{NO}_{3}-\mathrm{N}$ were 10 and $0.78 \mathrm{~cm}^{3} \mathrm{~g}^{-1}$ for all soil horizons (table 2), and were based on values from Bradshaw et al. (2013). Based on $R^{2}$ in model output, the adsorption coefficient was optimized across models using manual calibration to provide a more acceptable fit to observed $\mathrm{NO}_{3}-\mathrm{N}$ concentrations at the 8 and $75 \mathrm{~cm}$ depths.

Water content dependence of nitrification and denitrification were incorporated into the solute models. Water content dependence of reaction rates uses a modified version of the Walker (1974) equation 8:

$\omega(\theta)=\omega_{r}\left(\theta_{r e f}\right) \min \left[1,\left(\frac{\theta^{B}}{\theta_{r}}\right)\right]$,

where $\omega_{r}$ is the reaction rate constant $\left(\mathrm{d}^{-1}\right)$ at the reference water content $\left(\theta_{\text {red }}\right), \omega(\theta)$ is the rate constant $\left(\mathrm{d}^{-1}\right)$ at the actual water content $(\theta)$, and $B$ is a dimensionless solute-dependent parameter. Nitrification and denitrification rates were considered to be optimum at pressure heads of $-500 \mathrm{~cm}$ and $-20 \mathrm{~cm}$, respectively.

Model Initial Conditions and Inverse Data. The initial condition for soil pressure head at the uppermost observation node in each model was set to the corresponding water content that was measured at the beginning of the model period. The rest of the model space was set so that soil water movement was only due to gravitational flow (constant pressure head with depth). Inverse data for water content were input into HYDRUS-1D as the average daily measured volumetric water content of the three replications. Initial $\mathrm{NO}_{3}-\mathrm{N}$ concentrations were input into the model based on both soil samples and lysimeter samples taken immediately before corn planting. Average soil water $\mathrm{NO}_{3}-\mathrm{N}$ concentrations were determined by taking the average soil $\mathrm{NO}_{3}-\mathrm{N}$ level from the three replications and converting it to a concentration using the water content and bulk density of the soil.

Model Performance Criteria. Observed data in the model were average soil water content at the 8 and $23 \mathrm{~cm}$ depths and average soil water $\mathrm{NO}_{3}-\mathrm{N}$ concentration at the 8 and $75 \mathrm{~cm}$ depths. As a plot-scale model, no performance evaluation criteria are currently established in the literature for HYDRUS-1D that evaluate the agreement between predicted and observed data, and therefore determined by the objectives and statistical performance measures selected by the user (Moriasi et al. 2015). Therefore coefficient of determination $\left(R^{2}\right)$, PBIAS, and index of agreement $(d)$ were used to assess calibration and validation model performance along with visual inspection of graphical data.

$R^{2}$ describes the proportion of the variance in measured data explained by the model (Moriasi et al. 2007). $R^{2}$ ranges from 0 to 1 , and the degree of collinearity between predicted and observed data increases as values approach 1 (Moriasi et al. 2015). PBIAS measures whether the predicted data tend to be smaller or larger than their observed counterparts (Gupta et al. 1999). Positive values indicate an underestimation of water flow or $\mathrm{NO}_{3}-\mathrm{N}$ transport while negative values indicate overestimations of the parameters. Index of agreement $(d)$ is the ratio between the mean square error and the potential error with values ranging from 0 to 1 . As $d$ values approach 1 , the agreement between predicted and observed values increases (Willmott 1984).

\section{Results and Discussion}

Meteorological Conditions. The total rainfall during the model period from April 21, 2015, to February 29, 2016, was 1,236 $\mathrm{mm}$, of which $689 \mathrm{~mm}$ occurred between November and January (table 3). Drought occurred during most of 2016 to 2017 with rainfall totaling $706 \mathrm{~mm}$ between April 28, 2016, and February 26, 2017. Rainfall during the period of November through January in 2016 and 2017 was $311 \mathrm{~mm}$, less than half of that during 2015/2016.
Nitrogen Release from Living Mulch. An estimated 30.9 and $36.6 \mathrm{~kg} \mathrm{~N} \mathrm{ha}{ }^{-1}$ were released due to herbicide banding of the white clover in the LM plots in 2015 and 2016, respectively (Andrews et al. 2018). The total cumulative $\mathrm{N}$ release from LM clover at the end of the growing season was 139 and $149 \mathrm{~kg} \mathrm{~N} \mathrm{ha}^{-1}$ in 2015 and 2016, respectively.

Model Calibration and Validation. Data collected from the three replications of each treatment from April through August of 2015 were averaged and used to calibrate each model. Data collected from the three replications of each treatment from April of 2016 through February of 2017 were averaged and used to validate each model. Water flow calibration and validation $R^{2}$ values ranged from 0.57 to 0.70 and 0.67 to 0.71 , respectively (table 4). The PBIAS values for water flow ranged between $-2.9 \%$ and $10.8 \%$ for both calibration and validation models, and $d$ values ranged between 0.77 and 0.89 . Fitted values for the hydraulic parameters for the 0 to 18 and 18 to $38 \mathrm{~cm}$ depths differed from the initial values measured by the evaporation method (table 1). In the 0 to $18 \mathrm{~cm}$ depth, for example, $\theta_{r}$ decreased from 0.28 to 0.04 , $\theta$ decreased from 0.38 to $0.30, \alpha$ decreased from 0.0257 to 0.0062 , and $n$ decreased from 3.53 to 1.28 . These changes resulted in a less steep water retention curve and unsaturated $K(h)$ curve. However, it is not uncommon for fitted HYDRUS hydraulic parameters to differ from measured values (Bradshaw et al. 2013; Wang et al. 2010).

Calibration and validation $R^{2}$ values for $\mathrm{NO}_{3}-\mathrm{N}$ transport ranged from 0.83 to 0.91 and 0.41 to 0.77 , respectively (table 4 ). Percentage bias values ranged from $-38 \%$ to $14.5 \%$ and from $-8.1 \%$ to $0.4 \%$ for $\mathrm{cal}-$ ibration and validation, respectively. The calibration and validation $d$ values ranged between 0.81 and 0.97 , which is similar to those reported in other HYDRUS model simulations (Doltra and Muñoz 2010; Hu et al. 2008; Mubarak et al. 2009; Li et al. 2011). Generally, the level of agreement between observed and predicted data was not as strong for $\mathrm{NO}_{3}-\mathrm{N}$ transport when compared to the water flow models. This relationship is common for water and nutrient transport models, and the level of agreement necessary for nutrient transport modeling is typically lower than for water flow modeling (Moriasi et al. 2015). Graphical evaluation of model performance is presented in figures 1 through 3 . 
Table 2

Adsorption coefficients for ammonium-nitrogen $\left(\mathrm{NH}_{4}-\mathrm{N}\right)$ + potentially mineralizable $\mathrm{N}(\mathrm{PMN})$ and nitrate- $\mathrm{N}\left(\mathrm{NO}_{3}-\mathrm{N}\right)$, nitrification rate, and denitrification rate used for $\mathrm{N}$ transformation and transport in the HYDRUS-1D models.

\begin{tabular}{|c|c|c|c|c|}
\hline \multirow[b]{2}{*}{ Soil layer $(\mathbf{c m})$} & \multicolumn{2}{|c|}{ Adsorption coefficient $K_{d}\left(\mathrm{~cm}^{3} \mathrm{~g}^{-1}\right)$} & \multirow{2}{*}{$\begin{array}{l}\text { Nitrification rate } \\
k\left(d^{-1}\right)\end{array}$} & \multirow{2}{*}{$\begin{array}{l}\text { Denitrification rate } \\
\mu\left(\mathrm{d}^{-1}\right)\end{array}$} \\
\hline & $\mathrm{NH}_{4}-\mathrm{N}+\mathrm{PMN}$ & $\mathrm{NO}_{3}-\mathrm{N}$ & & \\
\hline 0 to 18 & 10.0 & 0.78 & 0.20 & 0.20 \\
\hline 18 to 38 & 10.0 & 0.78 & 0.20 & 0.20 \\
\hline 72 to 100 & 10.0 & 0.78 & 0.20 & 0.20 \\
\hline
\end{tabular}

\section{Table 3}

Monthly precipitation (P), irrigation (I), potential evaporation (PET), and average temperature in 2015, 2016, and 2017 at the J. Phil Campbell Research and Education Center in Watkinsville, Georgia.

\begin{tabular}{|c|c|c|c|c|c|c|c|c|c|c|}
\hline \multirow[b]{2}{*}{ Month } & \multicolumn{5}{|c|}{$2015 / 2016$} & \multicolumn{5}{|c|}{$2016 / 2017$} \\
\hline & $P(\mathbf{m m})$ & I (mm) & $\begin{array}{l}P+1 \\
(\mathrm{~mm})\end{array}$ & $\begin{array}{l}\text { PET } \\
(\mathbf{m m})\end{array}$ & $\begin{array}{l}\text { Avg. temp. } \\
\left({ }^{\circ} \mathrm{C}\right)\end{array}$ & $P(\mathbf{m m})$ & I (mm) & $\begin{array}{l}P+I \\
(\mathrm{~mm})\end{array}$ & $\begin{array}{l}\text { PET } \\
(\mathbf{m m})\end{array}$ & $\begin{array}{l}\text { Avg. temp. } \\
\left({ }^{\circ} \mathrm{C}\right)\end{array}$ \\
\hline April & 208 & 0 & 208 & 84 & 17.9 & 58 & 19 & 77 & 120 & 17.0 \\
\hline May & 47 & 78 & 125 & 138 & 21.6 & 32 & 95 & 127 & 143 & 20.8 \\
\hline June & 59 & 76 & 135 & 145 & 25.4 & 117 & 152 & 269 & 172 & 26.1 \\
\hline July & 131 & 19 & 150 & 147 & 26.7 & 33 & 114 & 147 & 169 & 27.2 \\
\hline October & 149 & 0 & 149 & 59 & 16.0 & 1 & 25 & 26 & 78 & 18.9 \\
\hline November & 235 & 0 & 235 & 25 & 13.3 & 40 & 57 & 97 & 37 & 13.0 \\
\hline December & 341 & 0 & 341 & 13 & 13.3 & 102 & 0 & 102 & 9 & 8.1 \\
\hline January & 113 & 0 & 113 & 23 & 5.3 & 167 & 0 & 167 & 28 & 10.3 \\
\hline February & 109 & 0 & 109 & 39 & 8.1 & 38 & 0 & 38 & 46 & 10.9 \\
\hline Total & 1,785 & 173 & 1,958 & 967 & - & 812 & 481 & 1,293 & 1,130 & - \\
\hline
\end{tabular}

\section{Table 4}

Coefficient of determination $\left(R^{2}\right)$, percentage bias (PBIAS), and index of agreement $(d)$ comparing agreement between observed and predicted water contents and nitrate-nitrogen $\left(\mathrm{NO}_{3}-\mathrm{N}\right)$ concentrations in the crimson clover (CC), living mulch (LM), and cereal rye (CR) HYDRUS-1D models.

\begin{tabular}{|c|c|c|c|c|c|c|c|}
\hline \multirow[b]{2}{*}{ System } & \multirow[b]{2}{*}{ Period } & \multicolumn{3}{|c|}{ Water content } & \multicolumn{3}{|c|}{$\mathrm{NO}_{3}-\mathrm{N}$ concentration } \\
\hline & & $R^{2}$ & PBIAS & $\boldsymbol{d}$ & $R^{2}$ & PBIAS & $\boldsymbol{d}$ \\
\hline \multirow[t]{2}{*}{ CC } & Calibration & 0.70 & 6.6 & 0.84 & 0.91 & -38.0 & 0.94 \\
\hline & Validation & 0.67 & -2.9 & 0.89 & 0.61 & 0.4 & 0.87 \\
\hline \multirow[t]{2}{*}{ LM } & Calibration & 0.57 & 4.1 & 0.82 & 0.83 & 14.5 & 0.90 \\
\hline & Validation & 0.68 & -2.5 & 0.89 & 0.41 & -8.1 & 0.92 \\
\hline \multirow[t]{2}{*}{$\mathrm{CR}$} & Calibration & 0.67 & 10.8 & 0.77 & 0.90 & -12.0 & 0.97 \\
\hline & Validation & 0.71 & 1.2 & 0.88 & 0.77 & -1.8 & 0.92 \\
\hline
\end{tabular}

Soil Water. Predicted cumulative water loss below $1 \mathrm{~m}$ was similar among the different cover crop treatments when calibrating the HYDRUS-1D model (figure 4). The majority of water moved through the soil profile after the corn was harvested in the fall of 2015. This can be attributed to the fact that precipitation + irrigation was equal to crop evapotranspiration during the corn growing season (Andrews et al. 2018). Therefore, little surplus water was available to move through the soil profile. The annual growth habit of corn limited crop water use after harvest, but the soil rehydrated and percolation occurred when rainfall exceeded evapotranspiration. This was particularly evident following intense rainfall in December of 2015 (figure 4).

The validation model predicted considerably less water loss at the $1 \mathrm{~m}$ soil depth in 2016/2017 (figure 4). Precipitation + irrigation was less than crop evapotranspiration during the corn growing season, which limited surplus water availability for vertical movement (figure 4). Cumulative water loss after corn harvest in 2016 was less in the LM treatment than the other cover crop treatments. Water use by the perennial white clover exceeded that of the reseeded annual cover crops during drought conditions in the fall and winter of 2016/2017. Predicted cumulative water loss in the LM system was less than that in the CC and CR systems, respectively (figure 4).

Nitrate Leaching. The calibration models predicted that $<1 \mathrm{~kg} \mathrm{NO}-\mathrm{N} \mathrm{ha}^{-1}$ was leached below $1 \mathrm{~m}$ during the corn growing season in 2015 (April through August) regardless of cover crop treatment (figure 4), likely due to reduced water flow during that period. However, rainfall events in the fall and winter of 2015/2016 caused soils to become saturated, and $\mathrm{NO}_{3}-\mathrm{N}$ leached for more than two months after corn harvest. There were no differences in water flow at 1 $\mathrm{m}$ among the cover crop treatments, though the LM treatment had approximately 50\% less cumulative $\mathrm{NO}_{3}-\mathrm{N}$ transport than the $\mathrm{CC}$ or CR treatments (figure 4 ).

The validation models predicted that there was limited $\mathrm{NO}_{3}-\mathrm{N}$ leaching in all treatments, mostly due to reduced precipitation and lower water percolation than the previous model period (figure 4). In fact, evapotranspiration exceeded total precipitation and irrigation during corn growth in 2016, and may have led to reduced mineralization of white clover residue (Andrews et al. 2018).

Reduced $\mathrm{NO}_{3}-\mathrm{N}$ leaching in the white clover LM system is consistent with similar 


\section{Figure 1}

Observed and predicted HYDRUS-1D model data for the crimson clover (CC) system for water content and soil water nitrate-nitrogen ( $\mathrm{NO}_{3}-\mathrm{N}$ ) concentration at the $8 \mathrm{~cm}$ depth, as well as soil water $\mathrm{NO}_{3}-\mathrm{N}$ concentration at the $75 \mathrm{~cm}$ depth. Calibration (2015/2016) data is in the left column and validation (2016/2017) data is in the right column, both beginning o days after corn planting (DAP) in April of each year.

(a)

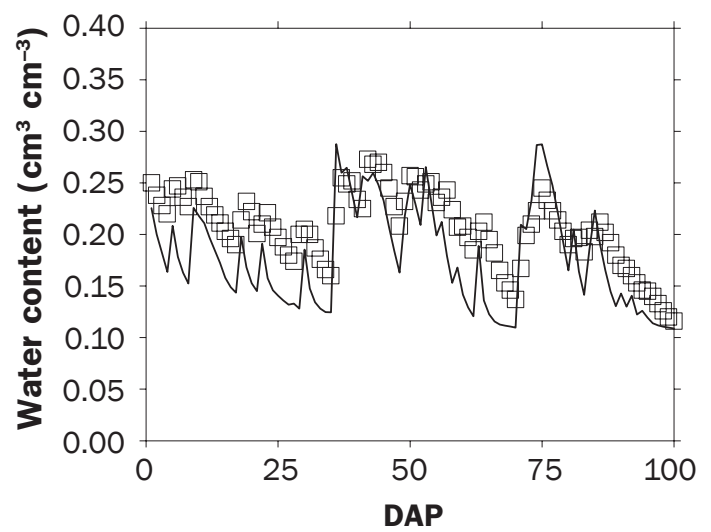

(c)

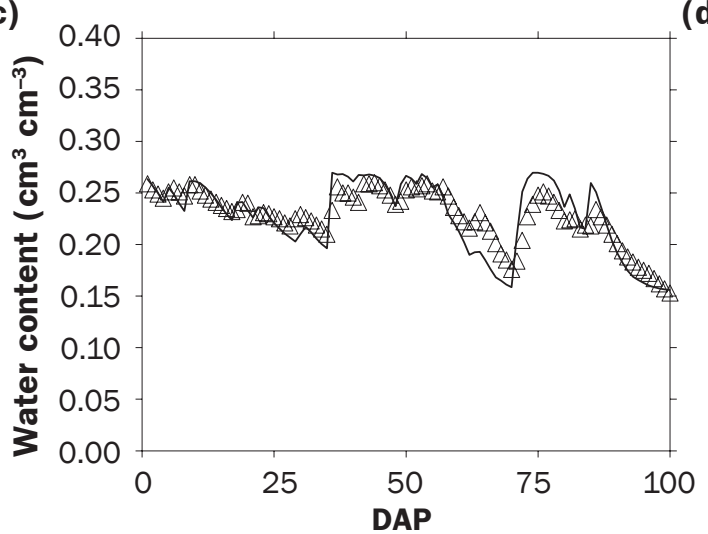

(b)

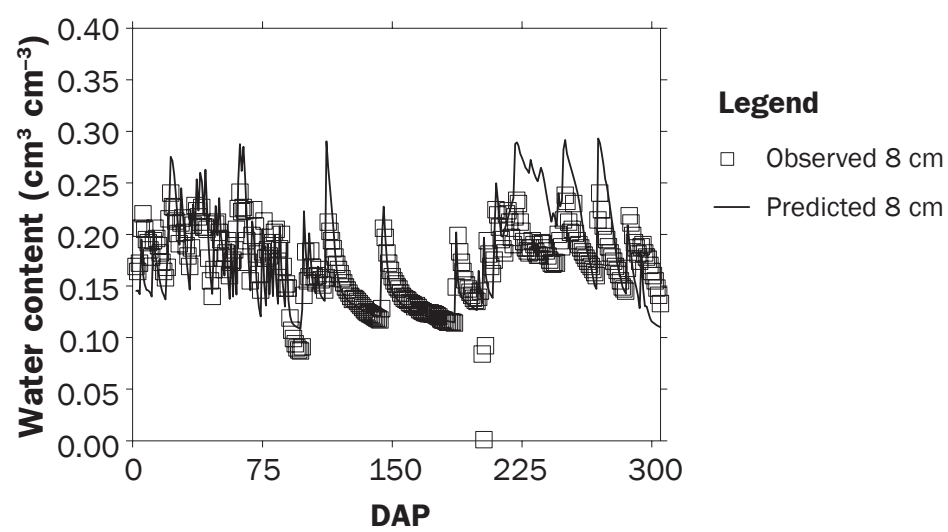

(d)

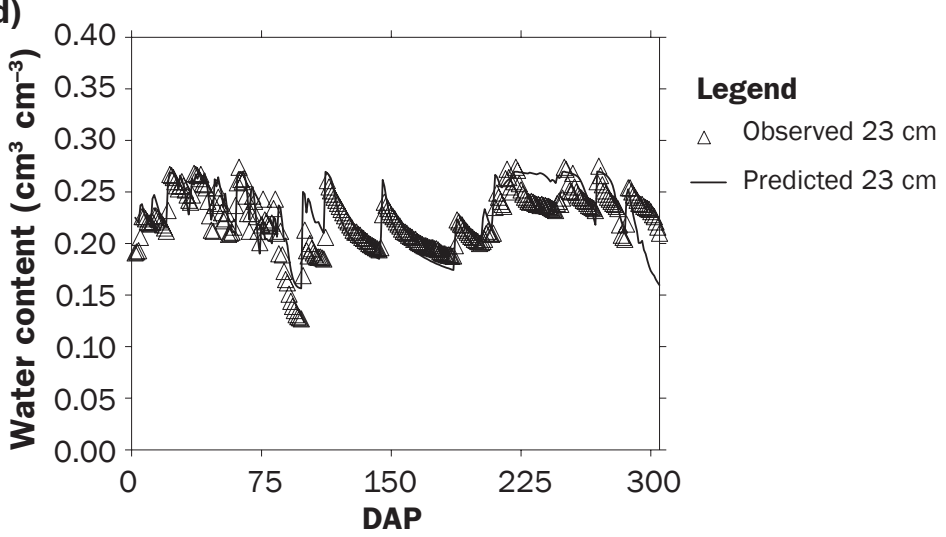

(e)

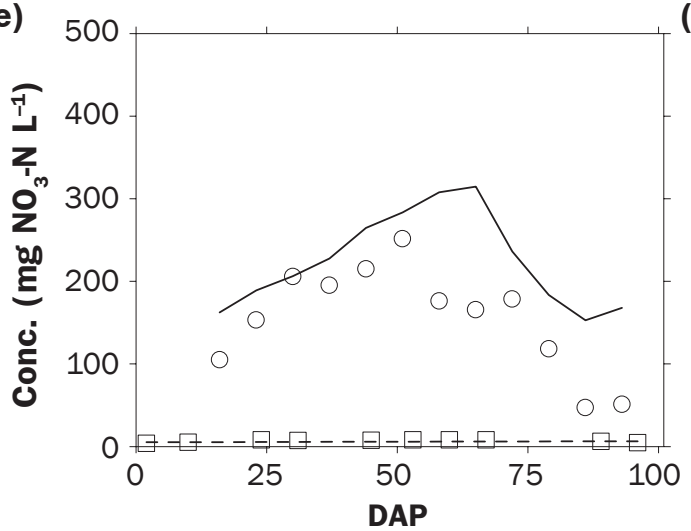

(f)

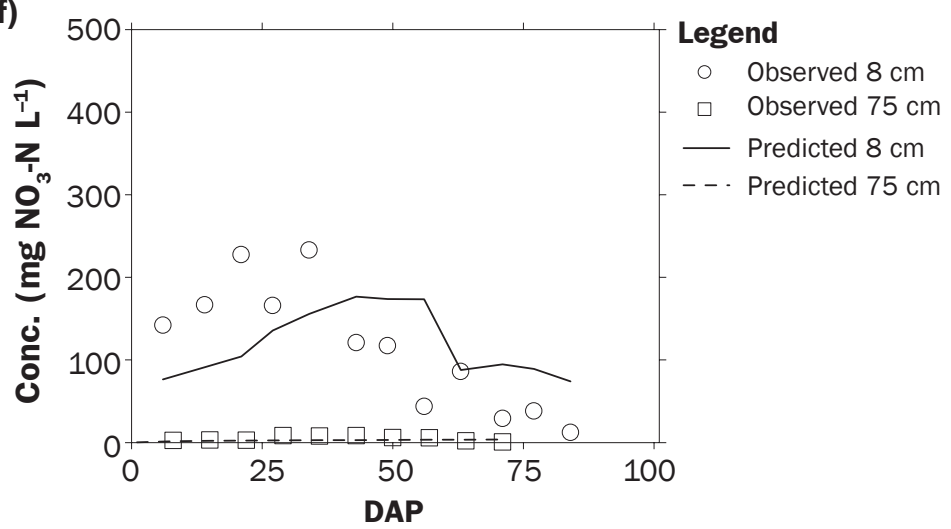

LM research (Liedgens et al. 2004; Ochsner et al. 2010). Leguminous LM systems have been found to have reduced soil $\mathrm{N}$ during and after the corn growing season, leading to less $\mathrm{N}$ vulnerable to leaching (Andrews et al. 2018; Ochsner et al. 2010; Zemenchik et al. 2000). These reductions have been attributed to competitive $\mathrm{N}$ uptake by the intercropped clover and reduced $\mathrm{N}$ mineralization during unfavorable environmental conditions, and can have a negative impact on overall corn growth and yield (Andrews et al. 2018; Kurtz et al. 1952; Liedgens et al. 2004; Ochsner et al. 2010). Reductions in soil moisture have also been reported in leguminous LM systems due to additional evapotranspiration by the intercropped clover, but this does not seem to dramatically affect percolation (figure 4) (Sanders et al. 2018; Ochsner et al. 2010; Zemenchik et al. 2000). Therefore, reduced soil $\mathrm{N}$ is likely the main cause of reduced $\mathrm{NO}_{3}-\mathrm{N}$ in leguminous LM systems (Ochsner et al. 2010).

The results herein are unique in that they show a reduction in $\mathrm{NO}_{3}-\mathrm{N}$ leaching in a perennial legume cover crop when compared to either grass or legume annual 
Figure 2

Observed and predicted HYDRUS-1D model data for the living mulch (LM) system for water content and soil water nitrate-nitrogen ( $\mathrm{NO}_{3}-\mathrm{N}$ ) concentration at the $8 \mathrm{~cm}$ depth, as well as soil water $\mathrm{NO}_{3}-\mathrm{N}$ concentration at the $75 \mathrm{~cm}$ depth. Calibration (2015/2016) data is in the left column and validation (2016/2017) data is in the right column, both beginning o days after corn planting (DAP) in April of each year.

(a)

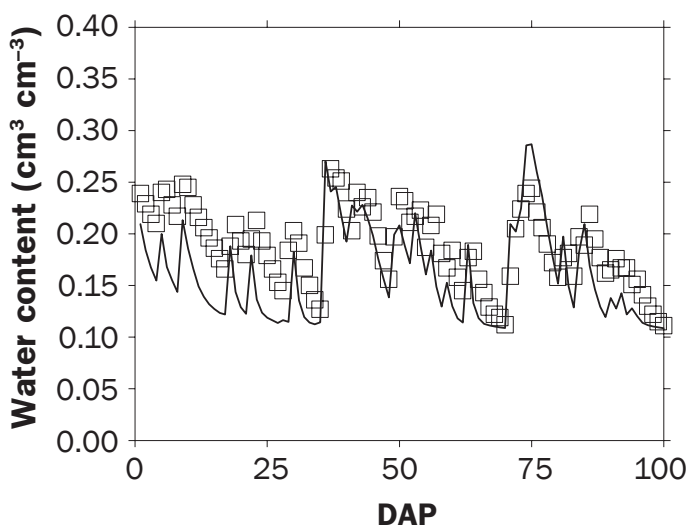

(c)

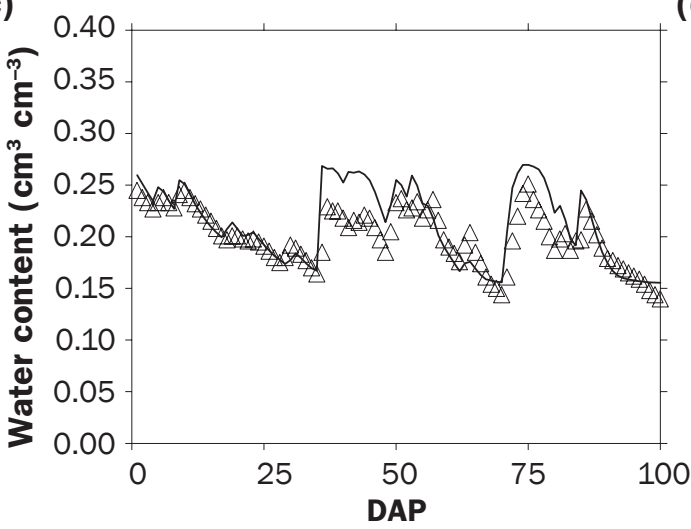

(e)

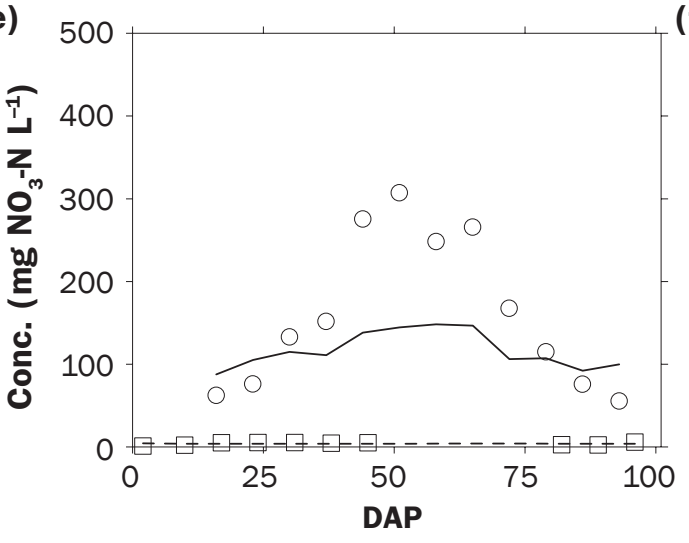

(b)

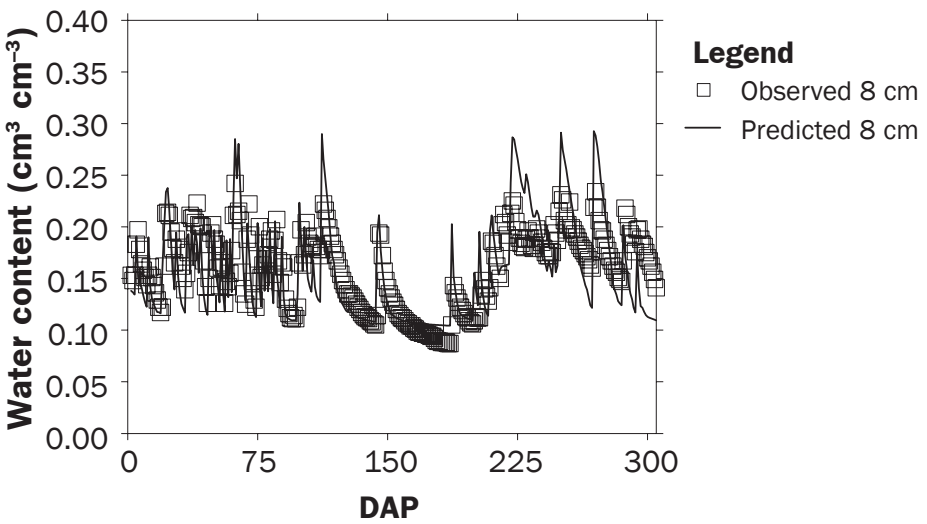

(d)

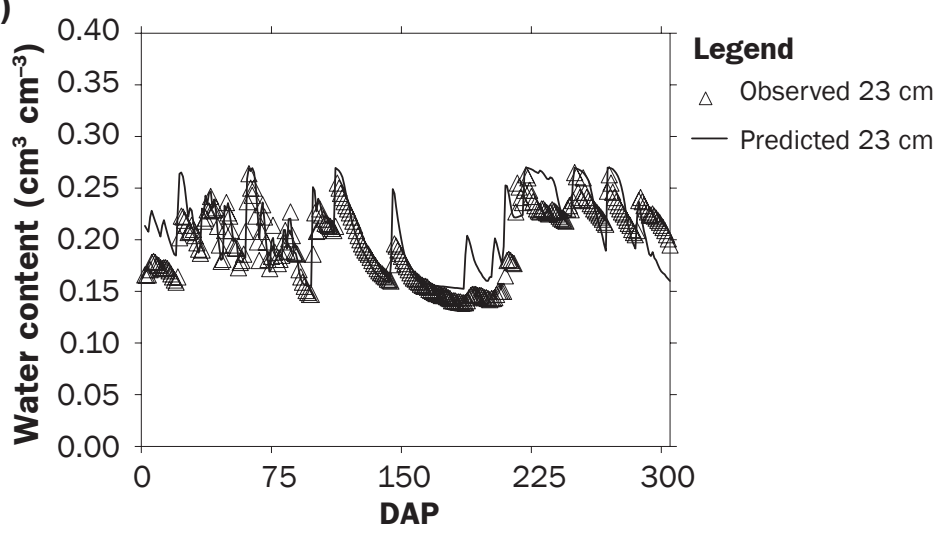

(f)

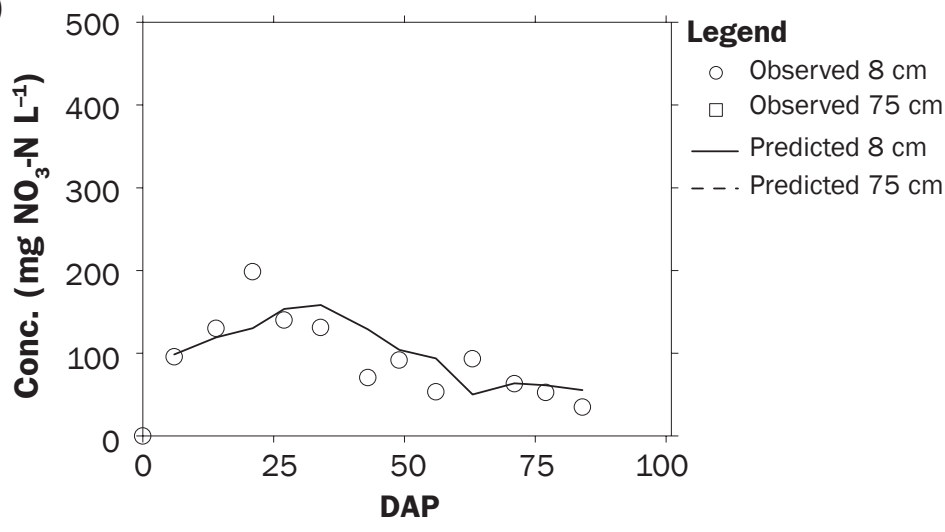

cover crops. In addition to reduced soil $\mathrm{N}$ after corn harvest, this may be attributed to residual $\mathrm{N}$ uptake by the white clover during regrowth. Although known for their $\mathrm{N}$-fixing capabilities, perennial legume cover crops may preferentially utilize excess soil $\mathrm{N}$, leading to a reduction of soil $\mathrm{N}$ susceptible to leaching (McCracken et al. 1994; Svenning and Macduff 1996). Nitrogen uptake in the white clover may also be aided by rapid white clover re-establishment, which has been shown to exceed $80 \%$ basal cover 100 days after corn harvest. However, cereal rye is considered to have a greater $\mathrm{N}$ uptake potential than legumes, and different levels of soil $\mathrm{N}$ after harvest make it difficult to compare $\mathrm{N}$ scavenging potential of the three systems (Andrews et al. 2018; Dabney et al. 2007).

\section{Summary and Conclusions}

The HYDRUS-1D model was able to successfully simulate the vertical water and $\mathrm{NO}_{3}-\mathrm{N}$ movement in LM and annual cover cropped corn production systems. Model predictions revealed that little leaching occurred during the corn growing season, but did occur during the dormant season when precipitation exceeded the water 


\section{Figure 3}

Observed and predicted HYDRUS-1D model data for the cereal rye (CR) system for water content and soil water nitrate-nitrogen ( $\mathrm{NO}_{3}-\mathrm{N}$ ) concentration at the $8 \mathrm{~cm}$ depth, as well as soil water $\mathrm{NO}_{3}-\mathrm{N}$ concentration at the $75 \mathrm{~cm}$ depth. Calibration (2015/2016) data is in the left column and validation (2016/2017) data is in the right column, both beginning o days after corn planting (DAP) in April of each year.

(a)

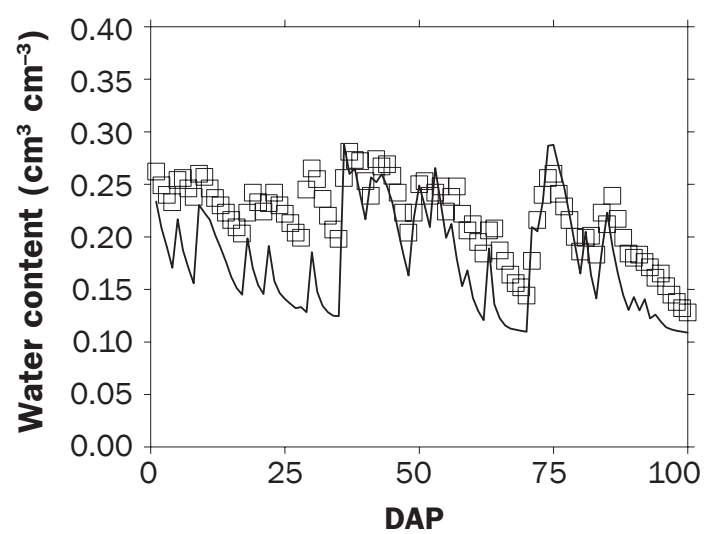

(c)

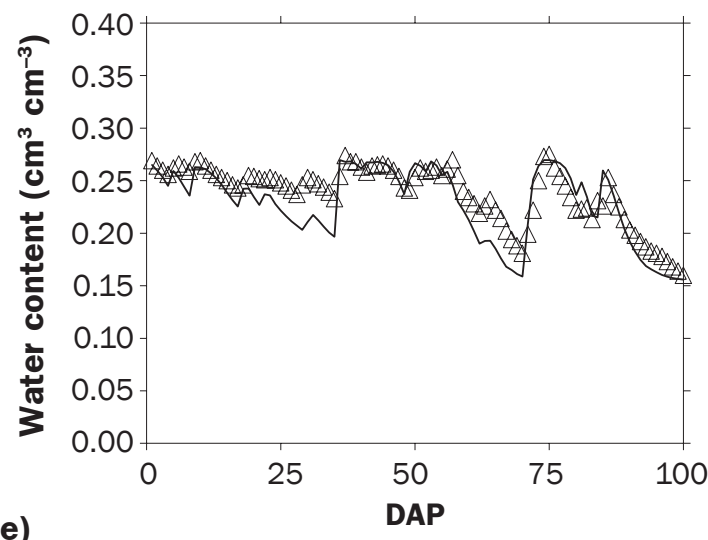

(e)

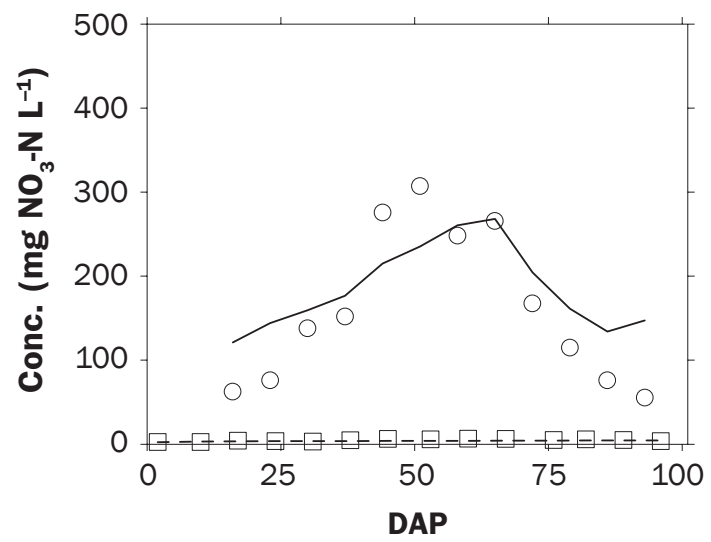

(b)

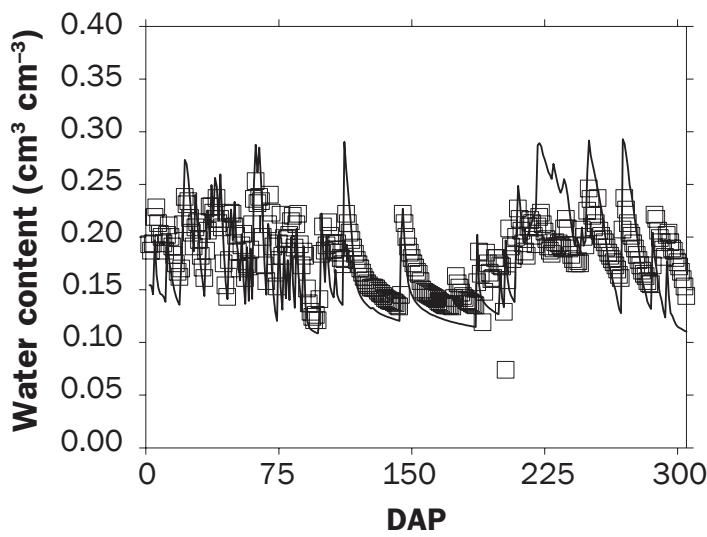

Legend

$\square \quad$ Observed $8 \mathrm{~cm}$

- Predicted $8 \mathrm{~cm}$

(d)

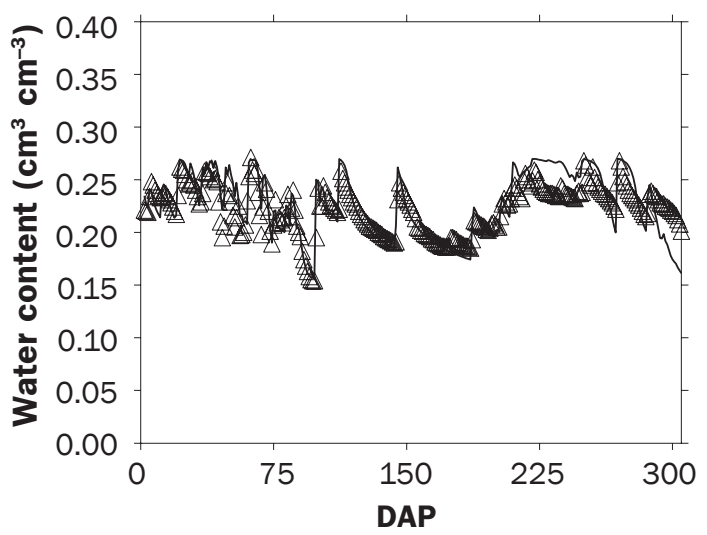

Legend

$\triangle$ Observed $23 \mathrm{~cm}$

- Predicted $23 \mathrm{~cm}$

(f)

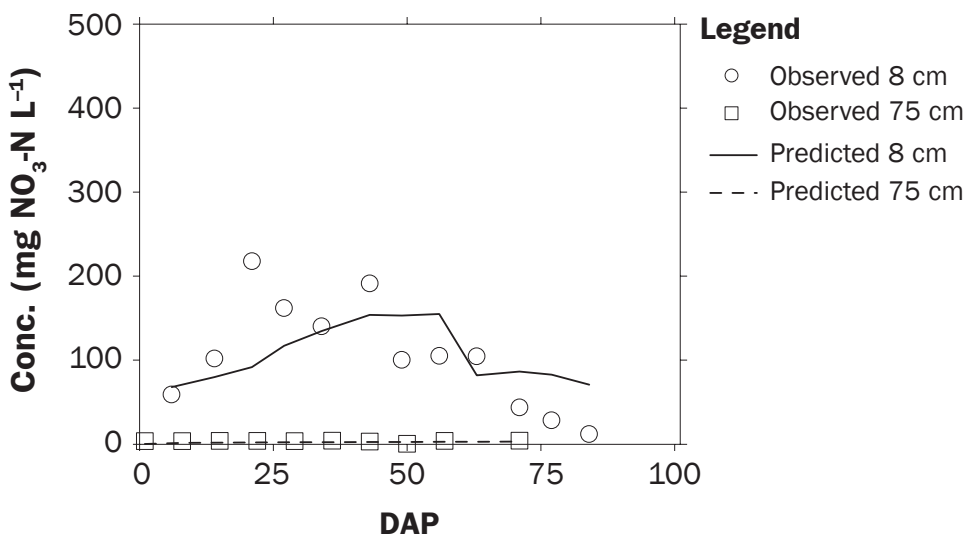

holding capacity of the soil. This study may be unique in that it suggests that $\mathrm{NO}_{3}-\mathrm{N}$ leaching in corn production may be reduced by a perennial LM cover crop when compared to annual cover crops. Reductions in $\mathrm{NO}_{3}-\mathrm{N}$ leaching are attributed to less residual soil $\mathrm{N}$ after corn harvest and $\mathrm{N}$ uptake by the white clover during regrowth. Therefore, the LM system may be enticing to producers as it reduces both mineral fertilizer inputs and $\mathrm{N}$ leaching losses without the need to re-establish like in annual cover cropping systems. However, future work is necessary to determine surface nutrient losses, atmospheric emissions, long-term $\mathrm{N}$ release from cover crops and soil organic matter, weed competition and herbicide use, and economic efficiency of the LM system for it to be fully considered a viable production strategy. 
Figure 4

Water drainage and nitrate-nitrogen ( $\mathrm{NO}_{3}-\mathrm{N}$ ) leaching during the two model periods from o to 315 days after planting (DAP), starting at corn planting in ( $\mathrm{a}$ and c) April of 2015 through February of 2016 and from corn planting in (b and d) April of 2016 through February of 2017. Water and $\mathrm{NO}_{3}-\mathrm{N}$ loss during the two periods is shown for the crimson clover (CC), living mulch (LM), and cereal rye (CR) corn production systems.
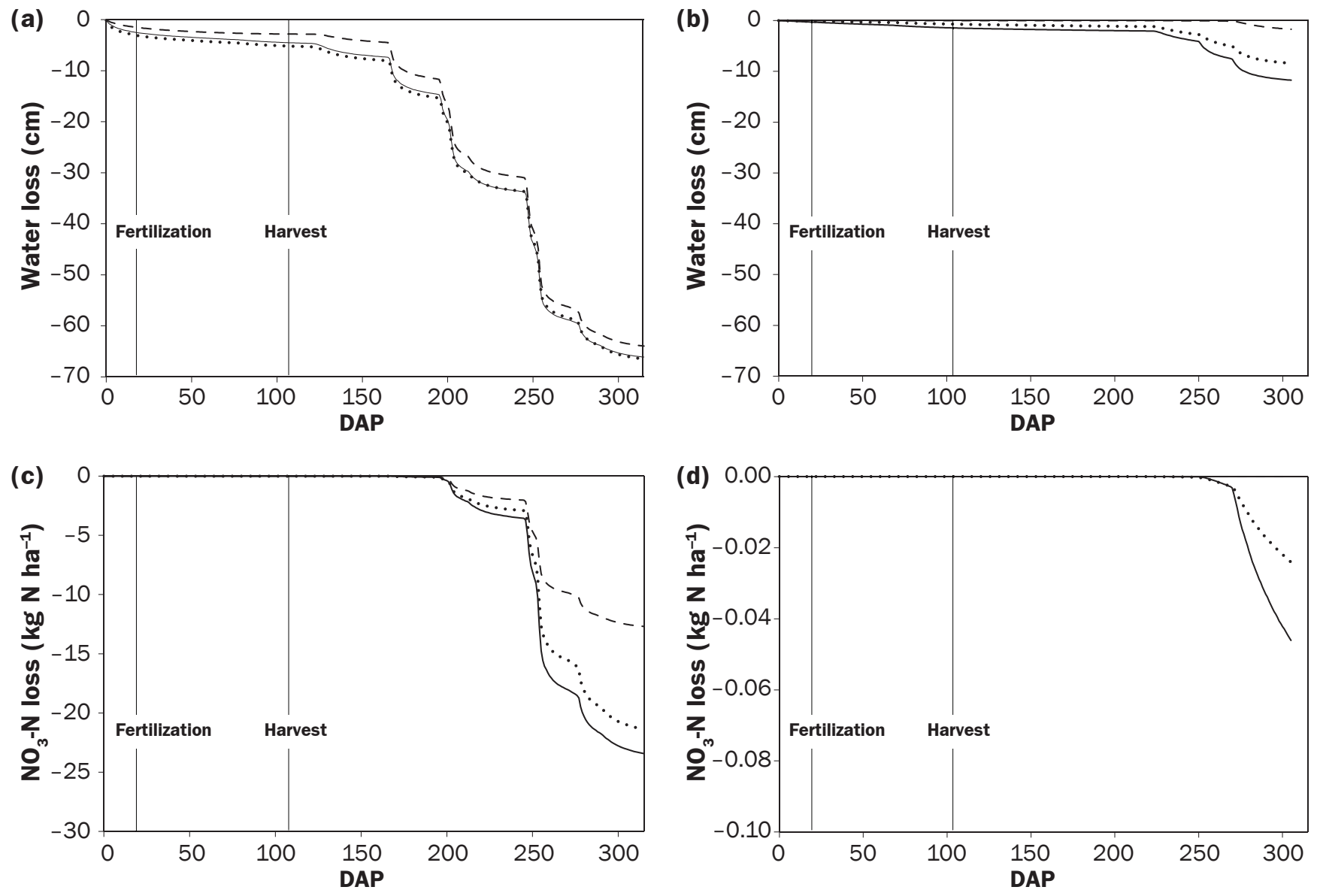

Legend

$\longrightarrow$ CC $\quad--\cdot$ LM $\quad$.....CR

\section{References}

Adams, W.E., H.D. Morris, and R.N. Dawson. 1970. Effect of cropping systems and nitrogen levels on corn (Zea mays) yields in the southern piedmont region. Agronomy Journal 62(5):655-659.

Anderson, O. 1960. The effect of low temperatures on nitrification of ammonia in Cecil sandy loam. Soil Science Society of America Journal 24(4):286-289.

Andraski, T.W., L.G. Bundy, and K.R. Brye. 2000. Crop management and corn nitrogen rate effects on nitrate leaching. Journal of Environmental Quality 29(4):1095-1103.

Andrews, J.S., Z.S. Sanders, M.L. Cabrera, U.K. Saha, and N.S. Hill. 2018. Nitrogen dynamics in living mulch and annual cover crop corn production systems. Agronomy Journal 110(4):1309-1317.

Angle, J.S., C.M. Gross, and M.S. McIntosh. 1989. Nitrate concentrations in percolate and groundwater under conventional and no-till Zea mays watersheds.
Agriculture, Ecosystems, and the Environment 25(4):279-286

Arora, Y., and A. Juo. 1982. Leaching of fertilizer ions in a kaolinitic Ultisol in the high rainfall tropics: Leaching of nitrate in field plots under cropping and bare fallow. Soil Science Society of America Journal 46(6):1212-1218.

Arya, L.M. 2002. Wind and hot-air methods. In Methods of Soil Analysis: Part 4, Physical Methods, ed.J.H. Dane and G.C. Topp, 916-926. Madison, WI: Soil Science Society of America.

Beck, M.A., L.W. Zelazny, W.L. Daniels, and G.L. Mullins. 2004. Using the Mehlich-1 extract to estimate soil phosphorus saturation for environmental risk assessment. Soil Science Society of America Journal 68(5):1762-1771.

Berntsen, J., B.M. Petersen, J.E. Olesen, J. Eriksen, and K. Soegaard. 2005. Simulation of residual effects and nitrate leaching after incorporation of different ley types. European Journal of Agronomy 23(3):290-304.
Bradshaw, J.K., D.E. Radcliffe, J. Šimůnek, A. Wunsch, and J.E. McCray. 2013. Nitrogen fate and transport in a conventional onsite wastewater treatment system installed in a clay soil: A nitrogen chain model. Vadose Zone Journal 12(3):1-20.

Brandi-Dohrn, F.M., M. Hess, J.S. Selker, R.P. Dick, S.M. Kauffman, and D.D. Hemphill. 1997. Nitrate leaching under a cereal rye cover crop. Journal of Environmental Quality 26(1):181-188.

Bruce, R.R., J. Dane, V. Quisenberry, N. Powell, and A. Thomas. 1983. Physical Characteristics of Soils in the Southern Region: Cecil. Southern Cooperative Series Bulletin 267. Athens, GA: University of Georgia.

Cabrera, M. 1993. Modeling the flush of nitrogen mineralization caused by drying and rewetting soils. Soil Science Society of America Journal 57(1):63-66.

Campiglia, E., R. Mancinelli, E. Radicetti, and S. Marinari. 2011. Legume cover crops and mulches: Effects on nitrate leaching and nitrogen input in a pepper crop (Capsicum 
annum L.). Nutrient Cycling in Agroecosystems 89(3):399-412.

Caradus, J. 1990. The structure and function of white clover root systems. Advances in Agronomy 43(1):1-46.

Carlsen, S.C.K., N.H. Spliid, and B. Svensmark. 2006. Drift of 10 herbicides after tractor spray application. 2. Primary drift (droplet drift). Chemosphere 64(5):778-786.

Dabney, S.M., J.A. Delgado, and D.W. Reeves. 2007. Using winter cover crops to improve soil and water quality. Communication in Soil Science and Plant Analysis Journal 32(7-8):1221-1250.

den Hollander, N., L. Bastiaans, and M. Kropff. 2007. Clover as a cover crop for weed suppression in an intercropping design: I. Characteristics of several clover species. European Journal of Agronomy 26(2):92-103.

Doltra, J., and P. Muñoz. 2010. Simulation of nitrogen leaching from a fertigated crop rotation in a Mediterranean climate using the EU-Rotate_N and Hydrus-2D models. Agricultural Water Management 97(2):277-285.

Dubey, H. 1968. Effect of soil moisture levels on nitrification. Canadian Journal of Microbiology 14(12):1348-1350.

Ellen, J. 1993. Growth, yield and composition of four winter cereals. I. Biomass, grain yield and yield formation. NJAS-Wageningen Journal of Life Sciences 41(2):153-165.

Enache, A.J., and R.D. Ilnicki. 1990. Weed control by subterranean clover (Trifolium subterraneum) used as a living mulch. Weed Technology 4(3):534-538.

Endale, D.M., H.H. Schomberg, D.S. Fisher, M.B. Jenkins, R.R. Sharpe, and M.L. Cabrera. 2008. No-till corn productivity in a southeastern United States Ultisol amended with poultry litter. Agronomy Journal 100(5):1401-1408.

Feddes, R.A. 1978. Simulation of field water use and crop yield. In Simulation of Plant Growth and Crop Production, eds. R.A. Feddes, H. Zaradny, and P.J. Kowalik, 194-209. Pudoc Wagineningen, Netherlands: Centre for Agricultural Publishing and Documentation.

Frank, D.L., and O.E. Liburd. 2005. Effects of living and synthetic mulch on the population dynamics of whiteflies and aphids, their associated natural enemies, and insect-transmitted plant diseases in zucchini. Environmental Entomology 34(4):857-865.

Gold, A.J., J.L. Lemunyon, W.M. Sullivan, and W.R. DeRagon. 1990. Nitrate-nitrogen losses to groundwater from rural and suburban land uses. Journal of Soil and Water Conservation 45(2):305-310.

Gupta, H.V., S. Sorooshian, and P.O. Yapo. 1999. Status of automatic calibration for hydrologic models: Comparison with multilevel expert calibration. Journal of Hydrologic Engineering 4(2):135-143.

Hahne, H.C.H., W. Kroontje, and J.A. Lutz. 1977. Nitrogen fertilization I. Nitrate accumulation and losses under continuous corn cropping. Soil Science Society of America Journal 41(3):562-567.
Hanson, B.R., J. Šimůnek, and J.W. Hopmans. 2006 Evaluation of urea-ammonium-nitrate fertigation with drip irrigation using numerical modeling. Agricultural Water Management 86(1-2):102-113.

Hartwig, N.L., and H.U. Ammon. 2002. Cover crops and living mulches. Weed Science 50(6):688-699.

Hashemi, M., A. Farsad, A. Sadeghpour, S.A. Weis, and S.J. Herbert. 2013. Cover-crop seeding-date influence on fall nitrogen recovery. Journal of Plant Nutrition and Soil Science 176(1):69-75.

Hendrickson, B., A. Barnett, J. Carreker, and W.Adams. 1963. Runoff and Erosion Control Studies on Cecil Soil in the Southern Piedmont. Technical Bulletin 1281. Athens, GA: USDA.

Hiltbrunner, J., M. Liedgens, L. Bloch, P. Stamp, and B. Streit. 2007. Legume cover crops as living mulches for winter wheat: Components of biomass and the control of weeds. European Journal of Agronomy 26(1):21-29.

Hu, K., B. Li, D. Chen, Y. Zhang, and R. Edis. 2008. Simulation of nitrate leaching under irrigated maize on sandy soil in desert oasis in Inner Mongolia, China. Agricultural Water Management 95(10):1180-1188.

Iskandar, I., and H. Selim. 1981. Modeling nitrogen transport and transformations in soils: 2 . validation. Soil Science 131(5):303-312.

Kanwar, R.S., J.L. Baker, and D.G. Baker. 1988. Tillage and split $\mathrm{N}$-fertilization effects on subsurface drainage water quality and crop yields. Transactions of the ASABE 31(2):452-461.

Ketterings, Q.M., S.N. Swink, S.W. Duiker, K.J. Czymmek, D.B. Beegle, and W.J. Cox. 2015. Integrating cover crops for nitrogen management in corn systems on northeastern US dairies. Agronomy Journal 107(4):1365-1376.

Kladivko, E.J., T.C. Kaspar, D.B.Jaynes, R.W. Malone, J. Singer, X.K. Morin, and T. Searchinger. 2014. Cover crops in the upper midwestern United States: Potential adoption and reduction of nitrate leaching in the Mississippi River Basin. Journal of Soil and Water Conservation 69(4):279-291, doi:10.2489/jswc.69.4.279.

Krueger, E.S., T.E. Ochsner, P.M. Porter, and J.M. Baker 2011. Winter rye cover crop management influences on soil water, soil nitrate, and corn development. Agronomy Journal 103(2):316-323.

Kurtz,T., S.W. Melsted, and R.H. Bray. 1952.The importance of nitrogen and water in reducing competition between intercrops and corn. Agronomy Journal 44(1):13-17.

Lee, R.D., G.H. Harris, K. Harrison, W. Porter, E. Prostko, D. Buntin, R. Kemerait, P. Sumner, N. Smith, and A. Smith. 2015. A Guide to Corn Production in Georgia 2015 Special Publication CSS 01-2015. Athens, GA: University of Georgia.

Li, J., and Y. Liu. 2011. Water and nitrate distributions as affected by layered-textural soil and buried dripline depth under subsurface drip fertigation. Irrigation Science 29(6):469-478.
Li, S., D. Zhou, Z. Luan,Y. Pan, and C. Jiao. 2011. Quantitative simulation on soil moisture contents of two typical vegetation communities in Sanjiang Plain, China. Chinese Geographical Science 21(6):723-733.

Liedgens, M.E., E. Frossard, and W. Richner. 2004. Interactions of maize and Italian ryegrass in a living mulch system II: Nitrogen and soil water dynamics. Plant and Soil 259(1-2):243-258.

Ling, G., and A.I. El-Kadi. 1998. A lumped parameter model for nitrogen transformation in the unsaturated zone. Water Resources Research 34(2):203-212.

Litsinger, J.A., and K. Moody. 1976. Integrated pest management in multiple cropping systems. In Multiple Cropping,ASA Special Publication 27, ed. R.I. Papendick, 239-316. Madison, WI:American Society of Agronomy.

Lotse, E., J.Jabro, K. Simmons, and D. Baker. 1992. Simulation of nitrogen dynamics and leaching from arable soils. Journal of Contaminant Hydrology 10(3):183-196.

McCracken, D.V., M.S. Smith, J.H. Grove, R.L. Blevins, and C.T. MacKown. 1994. Nitrate leaching as influenced by cover cropping and nitrogen source. Soil Science Society of America Journal 58(5):1476-1483.

Mengel, D., and S. Barber. 1974. Development and distribution of the corn root system under field conditions. Agronomy Journal 66(3):341-344.

Moriasi, D.N., J.G. Arnold, M.W. Van Liew, R.L. Bingner, R.D. Harmel, and T.L. Veith. 2007. Model evaluation guidelines for systematic quantification of accuracy in watershed simulations. Transactions of the ASABE 50(3):885-900.

Moriasi, D.N., M.W. Gitau, N. Pai, and P. Daggupati. 2015. Hydrologic and water quality models: Performance measures and evaluation criteria. Transactions of the ASABE 58(6):1763-1785.

Mubarak, I., J.C. Mailhol, R. Angulo-Jaramillo, S. Bouarfa, and P. Ruelle. 2009. Effect of temporal variability in soil hydraulic properties on simulated water transfer under high-frequency drip irrigation. Agricultural Water Management 96(11):1547-1559.

Ochsner, T.E., K.A. Albrecht, T.W. Schumacher, J.M. Baker, and R.J. Berkevich. 2010. Water balance and nitrate leaching under corn in kura clover living mulch. Agronomy Journal 102(4):1169-1178.

Radcliffe, D.E., and L.T. West. 2000. MLRA 136: Southern Piedmont. Southern Cooperative Series Bulletin 395. Athens, GA: University of Georgia.

Rasse, D.P., J.T. Ritchie, W.R. Peterson, J. Wei, and A.J.M. Smucker. 2000. Rye cover crop and nitrogen fertilization effects on nitrate leaching in inbred maize fields. Journal of Environmental Quality 29(1):298-304.

Raun, W.R., and G.V. Johnson. 1999. Improving nitrogen use efficiency for cereal production. Agronomy Journal 91(3):357-363.

Richards, L.A. 1931. Capillary conduction of liquids through porous mediums. Physics 1(5):318-333. 
Sainju, U.M., B.P. Singh, and W.F. Whitehead. 1998. Cover crop root distribution and its effects on soil nitrogen cycling. Agronomy Journal 90(4):511-518.

Sanders, Z.P., J.S. Andrews, and N.S. Hill. 2018. Water use efficiency in living mulch and annual cover crop corn production systems. Agronomy Journal 110(3):1128-1135.

Sanders, Z.P., J.S. Andrews, U.K. Saha, W.Vencill, R.D. Lee, and N.S. Hill. 2017. Optimizing agronomic practices for clover persistence and corn yield in a white clover-corn living mulch system. Agronomy Journal 109(5):2025-2032.

Siller,A.R., K.A.Albrecht, and W.E. Jokela. 2016. Soil erosion and nutrient runoff in corn silage production with Kura clover living mulch and winter rye. Agronomy Journal 108(3):989-999.

Šimůnek, J., M.T. van Genuchten, and M. Šejna. 2016. Recent developments and applications of the HYDRUS computer software packages. Vadose Zone Journal 15(7):1-25.

Singer, J.W. 2008. Corn Belt assessment of cover crop management and preferences. Agronomy Journal 100(6):1670-1672.

Sogbedji, J.M., H.M. van Es, C.L. Yang, L.D. Geohring, and F.R. Magdoff. 2000. Nitrate leaching and nitrogen budget as affected by maize nitrogen rate and soil type. Journal of Environmental Quality 29(6):1813-1820.

Staver, K.W., and R.B. Brinsfield. 1998. Using cereal gran winter cover crops to reduce groundwater nitrate contamination in the mid-Atlantic coastal plain. Journal of Soil and Water Conservation 53(3):230-240.

Svenning, M., and J. MacDuff. 1996. Low root temperature retardation of the mineral nitrogen induced decline in $\mathrm{N}_{2}$ fixation by a northern ecotype of white clover. Annals of Botany 77(6):615-621.

Tafteh, A., and A.R. Sepaskhah. 2012. Application of HYDRUS-1D model for simulating water and nitrate leaching from continuous and alternate furrow irrigated rapeseed and maize fields. Agricultural Water Management 113(1):19-29.

Thomas, P.J., T.W. Simpson, and J.C. Baker. 1989. Erosion effects on productivity of Cecil soils in the Virginia Piedmont. Soil Science Society of America Journal 53(3):928-933.

Timlin, D.J., D.H. Fleisher, A.R. Kemanian, and V.R. Reddy. 2014. Plant density and leaf area index effects on the distribution of light transmittance to the soil surface in maize. Agronomy Journal 106(5):1828-1837.

USDA. 1996. Soil survey investigations report no. 42. In Soil Survey Laboratory Methods Manual, ed. R. Burt. Lincoln, NE: National Soil Survey Center.

van Genuchten, M.T. 1980. A closed-form equation for predicting the hydraulic conductivity of unsaturated soils. Soil Science Society of America Journal 44(5):892-898.

Walker, A. 1974. A simulation model for prediction of herbicide persistence. Journal of Environmental Quality 3(4):396-401.
Wall, G.L., W.A. Pringle, and R.W. Sheard. 1991. Intercropping red clover with silage corn for soil erosion control. Canadian Journal of Soil Science 71(2):137-145.

Wang, H., X. Ju, Y. Wei, B. Li, L. Zhao, and K. Hu. 2010. Simulation of bromide and nitrate leaching under heavy rainfall and high-intensity irrigation rates in North China Plain. Agricultural Water Management 97(10):1646-1654

Wang, Z., J. Li, and Y. Li. 2014. Simulation of nitrate leaching under varying drip system uniformities and precipitation patterns during the growing season of maize in the North China Plain. Agricultural Water Management 142(1):19-28.

Wesseling, J., J. Elbers, P. Kabat, and B. Van den Broek. 1991. SWATRE: Instructions for Input. Wageningen, Netherlands: Winand Staring Centre.

Willmott, C.J.1984. On the evaluation of model performance in physical geography. In Spatial Statistics and Models, eds. G.L. Gaile and C.J. Wilmott, 443-460. Dordrect, Netherlands: D. Reidel Publishing Company.

Wu, L., and M.B. McGechan. 1999. Simulation of nitrogen uptake, fixation and leaching in a grass/white clover mixture. Grass and Forage Science 54(1):30-41.

Yadav, S.N. 1997. Formulation and estimation of nitratenitrogen leaching from corn cultivation. Journal of Environmental Quality 26(3):808-814.

Zemenchik, R.A., K.A. Albrecht, C.M. Boerboom, and J.G. Lauer. 2000. Corn production with kura clover as a living mulch. Agronomy Journal 92(4):698-705. 